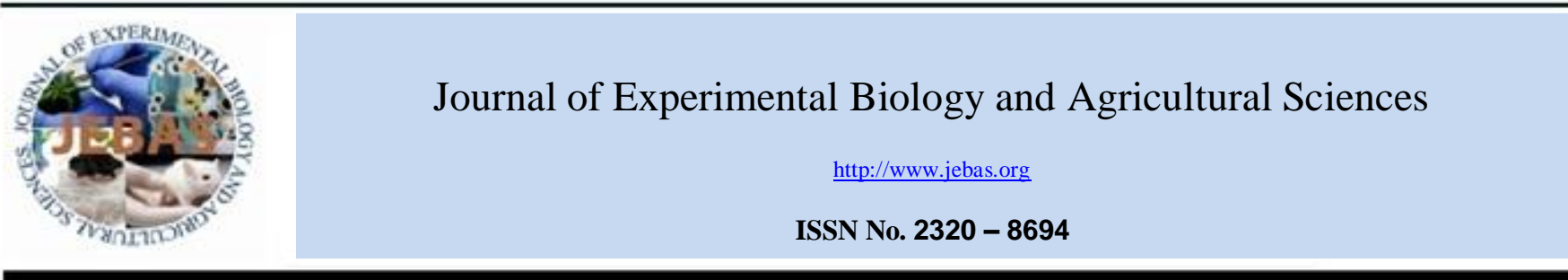

\title{
DETERMINING OF FLUORIDE CONTENT IN TEA BY SPECTROPHOTOMETERY AND POTENTIOMETRY
}

\section{Masoumeh Mahmoudi-Meymand, Saba Belgheisi*}

Faculty of Food Industry and Agriculture, Department of Food Science \& Technology, Standard Research Institute (SRI), Karaj P. O. Box 31745-139, Iran

Received - April 29, 2017; Revision - August 11, 2017; Accepted - September 03, 2017

Available Online - September 10, 2017

DOI: http://dx.doi.org/10.18006/2017.5(4).568.572

\section{KEYWORDS}

Fluoride content

Potentiometry

Spectrophotometry

Tea

\section{ABSTRACT}

Tea contains a high amount of fluoride and its consumption may affect the whole intake of fluoride. Excessive intake of fluoride over the long term may lead to the development of dental or skeletal fluorosis. In this study, fluoride content of 30 tea samples was determined using potentiometry and spectrophotometery. Results of study revealed that in determination of fluoride content potentiometric method is more precise than spectrophotometry. Further, results of study did not show any significant difference in the fluoride content of black and green tea, but the difference between the fluoride content of black tea bags with black and green tea is significant.
* Corresponding author

E-mail: s.belgheisi@gmail.com (Saba Belgheisi)

Peer review under responsibility of Journal of Experimental Biology and Agricultural Sciences.

Production and Hosting by Horizon Publisher India [HPI] (http://www.horizonpublisherindia.in/).

All rights reserved.
All the article published by Journal of Experimental Biology and Agricultural Sciences is licensed under a Creative Commons Attribution-NonCommercial 4.0 International License Based on a work at www.jebas.org.

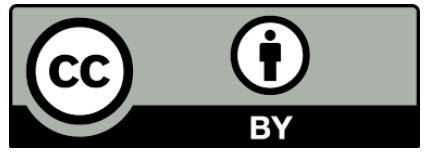




\section{Introduction}

Initially tea was used as a medical plant but later on it excessively used as herbal beverage (Kakuzo, 2011). Tea is a Chinese word which is used in China and north of India and it was introduced into Persian language with the same pronunciation. This plant was identified 5000 years ago in China and its medicinal properties were gradually discovered. For many years, it was used only in China; it entered Poland at the beginning of the $18^{\text {th }}$ century and, from there, it was introduced into other European countries.

Tea is classified into three main groups: black, green and oolong, depending on the way of production. Fourth class i.e. white tea which is made in a different way from other categories. After water, tea infusion is the most favorite beverage in the world. It contains caffeine, theophilin, tanin, tianin, catechin, vitamin, flavonoide, antioxidant, calcium, magnesium, sodium and potassium (Chung et al., 2003). It also contains a relatively high amount of fluoride and its consumption can affect total fluoride absorption inside the body. Fluoride is an important anion which is found in foods and water and its small amount is necessary to prevent dental disorders. Also, its average daily intake decreases dental decay in children and adults (Levi et al., 1983; Malinocuska et al., 2008).

Drinking tea is one of the most important sources of fluoride intake in Iran and other far-cast countries, because tea drinking is part of daily regime in these countries. Although fluoride content of tea is an important factor in the dental skeleton but intake in high amount of fluoride can causes dental and skeleton fluorosis (Shu et al., 2003; Institute of Medicine, 1997). This issue becomes more serious when fluoride intake from tea is added to fluoride intake from other sources like drinking water and food (Webb Peploe \& Bradley, 1996). Similarly, Cao et al. (1996) reported that $51.2 \%$ of the total dental fluorosis and $32.83 \%$ of the total skeleton fluorosis among Tabat children are because of the long term tea consumption.

Present study was conducted to access the fluoride content in different tea samples collected from Tehran market. Further efficacy of two fluoride estimation methods (potentiometry and spectrophotometry) in determination of total fluoride content was also evaluated in present study.

\section{Materials and Methods}

30 tea samples (including importing and local teas) were collected from Tehran market. These samples included: 15 black tea, 4 green tea, 5 black tea bags and 6 green tea bags. Fluoride content of the collected tea samples were analyzed by potentiometry (fluoride ion-selective electrode) and spectrophotometry methods.

\subsection{Black \& Green Tea preparation}

$100 \mathrm{~g}$ of each sample was equally divided into 4 parts; from this $10 \mathrm{~g}$ samples were randomly taken and thoroughly mixed. Then, it was dried for $4 \mathrm{~h}$ at $60^{\circ} \mathrm{C}$ and $2 \mathrm{~g}$ was used for the analysis. Further, four samples were prepared by adding $200 \mathrm{ml}$ of $100^{\circ} \mathrm{C}$ distilled water to each sample and was put on water bath for 10 minutes (at $100^{\circ} \mathrm{C}$ ). Then, it was cooled down to reach the room temperature, filtered and again make the volume $200 \mathrm{ml}$.

\subsection{Black \& Green Tea Bags preparation}

Four bags from each black and green tea bag were randomly taken and thoroughly mixed. Then, they were dried for $4 \mathrm{~h}$ at $60^{\circ} \mathrm{C}$ and $2 \mathrm{~g}$ sample was used for the analysis. Rest of the preparation was according to the method described for the black and green tea preparation.

\subsection{Potentiometry}

\subsubsection{Preparation of Tisab buffer}

$58.5 \mathrm{~g} \mathrm{NaCl}+66 \mathrm{~g}$ sodium acetate $+14.2 \mathrm{ml}$ glacial acid acetic were dissolved in the sufficient amount of distilled water. Then, 1g CDTA (1,2 cyclohexylen dinitrilo tetra acetic acid) was added and completely dissolved and reached to 1 lit with distilled water.

\subsubsection{Stock solution}

Standard solutions with the concentration of $10 \mathrm{mg} / \mathrm{kg}$ and 100 $\mathrm{mg} / \mathrm{kg}$ were prepared from the standard solution of $1000 \mathrm{mg} / \mathrm{kg}$.

\subsubsection{Standard solution:}

$0.5,1$ and $2 \mathrm{ml}$ of standard solutions $(10 \mathrm{mg} / \mathrm{kg}$ and $100 \mathrm{mg} / \mathrm{kg}$ ) moved to 6 flasks of $50 \mathrm{ml}$ and brought to volume with distilled water and standard solutions with concentrations $0.1,0.2,0.4,1,2$ and $4 \mathrm{mg} / \mathrm{kg}$ were prepared, respectively. Potentiometry was calibrated using fluoride electrode. $10 \mathrm{ml}$ of each standard solution was transferred to separate tubes and $10 \mathrm{ml}$ of Tisab buffer was added to each one. The absorption of each solution was determined at the wavelength of $620 \mathrm{~nm}$. Then, calibration curve was plotted (according to $\log$ concentration). $10 \mathrm{ml}$ of Tisab buffer was added to the sample solution and its absorption was read at $620 \mathrm{~nm}$ wavelength. Then, according to calibration curve, the amount of fluoride was determined.

\subsection{Spectrophotometery}

\subsubsection{Preparing of acetate buffer solution}

$60 \mathrm{~g}$ sodium acetate anhydrose was dissolved in $600 \mathrm{ml}$ distilled water. Then, $100 \mathrm{ml}$ glacial lactic acid was added and reached to 1 lit with distilled water. 


\subsubsection{Alizarin Fluorine}

960mg Alizarin Fluorine $\left[\mathrm{C}_{14} \mathrm{H}_{7} \mathrm{O}_{4} \mathrm{CH}_{2} \mathrm{~N}\left(\mathrm{CH}_{2} \mathrm{COOH}\right)_{2}\right]$ was dissolved in $100 \mathrm{ml}$ distilled water and reached to $250 \mathrm{ml}$ with distilled water in a flask (kept in the refrigerator).

\subsubsection{Coloring working solution}

$300 \mathrm{ml}$ buffer $+150 \mathrm{ml}$ acetone $+50 \mathrm{ml}$ tertiary butanol+ $36 \mathrm{ml}$ alizarin fluorine $+40 \mathrm{ml}$ lanthanum nitrate $+2 \mathrm{ml}$ polyoxyethylen lauryl ether 23 were mixed and volume were prepared to 1 lit with distilled water.

\subsubsection{Stock standard solution:}

Standard stock solution $10 \mathrm{ppm}$ was prepared from $1000 \mathrm{ppm}$ absolute solution with the help of distilled water.

\subsubsection{Working standard solution:}

$0.2,0.4,0.8,1.2,1.6$ and $2 \mathrm{ppm}$ standard solutions were prepared from $10 \mathrm{ppm}$ solution. $10 \mathrm{ml}$ of each solution were mixed with 10 $\mathrm{ml}$ coloring working solution. After $1 \mathrm{~h}$, the absorption of each solution was determined at the wavelength of $620 \mathrm{~nm}$. The calibration curve was plotted. Also, $10 \mathrm{ml}$ of coloring working solution was added to the sample solution and shaken. After $1 \mathrm{~h}$, the absorption was determined and the amount of fluoride was specified according to the calibration curve.

\subsection{Statistical Analysis}

The results of fluoride determinations were presented as means of mean \pm standard deviation $(\mathrm{x} \pm \mathrm{SD})$. Data were analyzed using ANOVA in SPSS15. Significant level was considered $\alpha=0.05$.

\section{Results and Discussion}

The fluoride levels of black tea, green tea and tea bags are listed in Tables 1-3. Results of study revealed a significant difference in the determination of fluoride content. The accuracy of results was studied by using both spectrophotometery and potentiometry and reported $72.9 \%$ and $98 \%$ fluoride recovery respectively. So, the results obtained from the potentiometry were analyzed and those of spectrophotometery results were excluded.

In present study, fluoride content was reported $0.48-1.85 \mathrm{mg} / \mathrm{L}$, 0.73-3.39 mg/L, 0.34-4.09 mg/L and 1.3-3.85 mg/L in black teas, green teas, black tea bags and green tea bags, respectively. Results showed that the amount of fluoride in black teas was less than that of green teas and tea bags contained the greatest amount of fluoride. Further, no significant difference was reported between the fluoride content of black and green teas ( $>0.05)$, while the difference in fluoride content of green and black tea bags was
Table1 Fluoride content in tea samples by potentiometry

\begin{tabular}{|c|c|c|c|}
\hline \multirow[t]{2}{*}{ No } & \multirow[t]{2}{*}{ Code } & $\begin{array}{c}\text { Fluoride in dry } \\
\text { material }(\mathrm{mg} / \mathrm{kg})\end{array}$ & $\begin{array}{l}\text { Fluoride in the tea } \\
\text { infusion (mg/lit) }\end{array}$ \\
\hline & & $\mathrm{X} \pm \mathrm{SD}$ & $\mathrm{X} \pm \mathrm{SD}$ \\
\hline 1 & BT01 & $5.5 \pm 86.3$ & $0.05 \pm 0.86$ \\
\hline 2 & BT02 & $3.2 \pm 126.0$ & $0.03 \pm 1.26$ \\
\hline 3 & BT03 & $1.9 \pm 182.8$ & $0.02 \pm 1.83$ \\
\hline 4 & BT04 & $2.3 \pm 47.8$ & $0.06 \pm 0.48$ \\
\hline 5 & BT05 & $2.4 \pm 90.7$ & $0.02 \pm 0.91$ \\
\hline 6 & BT06 & $5.5 \pm 182.4$ & $0.06 \pm 1.82$ \\
\hline 7 & BT07 & $3.9 \pm 85.6$ & $0.04 \pm 0.86$ \\
\hline 8 & BT08 & $4.6 \pm 159.8$ & $0.05 \pm 1.6$ \\
\hline 9 & BT09 & $5.5 \pm 66.2$ & $0.06 \pm 0.66$ \\
\hline 10 & BT10 & $2.1 \pm 81.9$ & $0.02 \pm 0.82$ \\
\hline 11 & BT11 & $3.3 \pm 65.1$ & $0.03 \pm 0.65$ \\
\hline 12 & BT12 & $2.7 \pm 129.1$ & $0.02 \pm 1.29$ \\
\hline 13 & BT13 & $3.1 \pm 184.7$ & $0.03 \pm 1.85$ \\
\hline 14 & BT14 & $4.2 \pm 62.9$ & $0.04 \pm 0.63$ \\
\hline 15 & BT15 & $1.9 \pm 129.2$ & $0.02 \pm 1.29$ \\
\hline 16 & ВТВ01 & $5.5 \pm 337.0$ & $0.06 \pm 0.34$ \\
\hline 17 & ВТВ02 & $6.5 \pm 101.3$ & $0.07 \pm 1.01$ \\
\hline 18 & ВТВ03 & $14.2 \pm 408.8$ & $0.14 \pm 4.09$ \\
\hline 19 & ВТВ04 & $10.3 \pm 133.8$ & $0.1 \pm 1.34$ \\
\hline 20 & ВТВ05 & $3.9 \pm 143.9$ & $0.04 \pm 1.44$ \\
\hline 21 & GT01 & $3.4 \pm 161.7$ & $0.03 \pm 1.62$ \\
\hline 22 & GT02 & $7.4 \pm 338.5$ & $0.07 \pm 3.39$ \\
\hline 23 & GT03 & $3.7 \pm 125.6$ & $0.04 \pm 1.26$ \\
\hline 24 & GT04 & $3.1 \pm 73.0$ & $0.03 \pm 0.73$ \\
\hline 25 & GTB01 & $3.8 \pm 129.6$ & $0.04 \pm 1.3$ \\
\hline 26 & GTB02 & $4.0 \pm 307.4$ & $0.04 \pm 3.07$ \\
\hline 27 & GTB03 & $13.5 \pm 335.5$ & $0.14 \pm 3.36$ \\
\hline 28 & GTB04 & $7.9 \pm 272.9$ & $0.08 \pm 2.73$ \\
\hline 29 & GTB05 & $8.6 \pm 384.6$ & $0.09 \pm 3.85$ \\
\hline 30 & GTB06 & $10.1 \pm 23.05$ & $0.1 \pm 2.31$ \\
\hline
\end{tabular}

$\mathrm{BT}=\mathrm{Black}$ Tea $\mathrm{BTB}=\mathrm{Black}$ Tea Bag, GT= Green Tea, GTB= Green Tea Bag

significant $(\mathrm{p}<0.05)$. Regarding the recommendation of daily fluoride intake by FAO and average daily consumption of four cups $(1000 \mathrm{ml})$, it can be concluded that tea bag samples are unsafe for children while black and green tea samples are safe for both children and adults. Out of the 30 analyzed samples, 7 samples ( 1 green tea with the average fluoride content of 3.39 
Table 2 Fluoride content in tea samples with spectrophotometry

\begin{tabular}{|c|c|c|c|}
\hline No & Code & $\begin{array}{c}\text { Fluoride in dry } \\
\text { material }(\mathrm{mg} / \mathrm{kg}) \\
\mathrm{X} \pm \mathrm{SD}\end{array}$ & $\begin{array}{c}\text { Fluoride in the tea } \\
\text { infusion ( } \mathrm{mg} / \mathrm{lit}) \\
\mathrm{X} \pm \mathrm{SD}\end{array}$ \\
\hline 1 & BT01 & $8.9 \pm 3.46$ & $04.47 \pm 0.0$ \\
\hline 2 & ВТ02 & $2.5 \pm 5.63$ & $05.64 \pm 0.0$ \\
\hline 3 & ВТ03 & $9.4 \pm 5.120$ & $06.21 \pm 0.1$ \\
\hline 4 & BT04 & $2.1 \pm 3.42$ & $03.42 \pm 0.0$ \\
\hline 5 & ВT05 & $7.7 \pm 3.46$ & $04.47 \pm 0.0$ \\
\hline 6 & BT06 & $3.2 \pm 6.82$ & $06.82 \pm 0.0$ \\
\hline 7 & ВT07 & $2.7 \pm 3.40$ & $03.41 \pm 0.0$ \\
\hline 8 & BT08 & $4.6 \pm 5.80$ & $05.81 \pm 0.0$ \\
\hline 9 & ВТ09 & $4.5 \pm 3.42$ & $03.43 \pm 0.0$ \\
\hline 10 & BT10 & $7.9 \pm 2.35$ & $02.36 \pm 0.0$ \\
\hline 11 & BT11 & $1.3 \pm 3.35$ & $03.35 \pm 0.0$ \\
\hline 12 & BT12 & $1.6 \pm 3.47$ & $03.48 \pm 0.0$ \\
\hline 13 & BT13 & $8.3 \pm 4.75$ & $05.75 \pm 0.0$ \\
\hline 14 & BT14 & $7.7 \pm 3.69$ & $04.7 \pm 0.0$ \\
\hline 15 & BT15 & $5.7 \pm 2.37$ & $03.38 \pm 0.0$ \\
\hline 16 & ВТВ01 & $4.4 \pm 2.41$ & $02.41 \pm 0.0$ \\
\hline 17 & ВТВ02 & $2.6 \pm 3.53$ & $03.54 \pm 0.0$ \\
\hline 18 & ВТВ03 & $8.4 \pm 10.277$ & $11.77 \pm 0.2$ \\
\hline 19 & ВТВ04 & $1.0 \pm 5.67$ & $05.67 \pm 0.0$ \\
\hline 20 & ВТВ05 & $1.1 \pm 4.165$ & $14.65 \pm 0.1$ \\
\hline 21 & GT01 & $5.8 \pm 6.82$ & $07.83 \pm 0.0$ \\
\hline 22 & GT02 & $3.207 \pm 8$ & $08.07 \pm 0.2$ \\
\hline 23 & GT03 & $0.0 \pm 4.59$ & $04.59 \pm 0.0$ \\
\hline 24 & GT04 & $6.0 \pm 2.33$ & $03.33 \pm 0.0$ \\
\hline 25 & GTB01 & $4.4 \pm 6.76$ & $06.76 \pm 0.0$ \\
\hline 26 & GTB02 & $4.5 \pm 6.194$ & $06.95 \pm 0.1$ \\
\hline 27 & GTB03 & $9.6 \pm 10.203$ & $11.04 \pm 0.2$ \\
\hline 28 & GTB04 & $3.83 \pm 13.172$ & $13.73 \pm 0.1$ \\
\hline 29 & GTB05 & $5.9 \pm 30.301$ & $21.02 \pm 0.3$ \\
\hline 30 & GTB06 & $9.7 \pm 5.160$ & $06.61 \pm 0.1$ \\
\hline
\end{tabular}

BT=Black Tea $\mathrm{BTB}=$ Black Tea Bag, GT $=$ Green Tea, GTB= Green Tea Bag

$\mathrm{mg} / \mathrm{L}, 1$ black tea bag with the average fluoride content of 4.09 $\mathrm{mg} / \mathrm{L}, 5$ green tea bags with average fluoride content of 3.07 , $3.36,2.73,3.85$ and $2.31 \mathrm{mg} / \mathrm{L}$ ) contained higher fluoride amount than the daily intake recommended by WHO $(2 \mathrm{mg} / \mathrm{L})$.

Fluoride is an essential element in human diet and it plays important role in teeth and bone mineralization, inhibitory and
Table 3 Comparison of fluoride content in tea samples by potentiometry

\begin{tabular}{|cccc|} 
Tea & $\begin{array}{c}\text { Number of } \\
\text { samples }\end{array}$ & $\begin{array}{c}\text { Fluoride in dry } \\
\text { material } \\
(\mathrm{mg} / \mathrm{kg}) \\
\mathrm{X} \pm \mathrm{SD}\end{array}$ & $\begin{array}{c}\text { Fluoride in the } \\
\text { tea infusion } \\
(\mathrm{mg} / \mathrm{lit}) \\
\mathrm{X} \pm \mathrm{SD}\end{array}$ \\
\hline Black tea & 15 & $47.7^{\mathrm{a}} \pm 112.1$ & $0.4^{\mathrm{a}} \pm 1.1$ \\
\hline Green tea & 4 & $115.1^{\mathrm{a}} \pm 174.7$ & $1.1^{\mathrm{a}} \pm 1.7$ \\
\hline $\begin{array}{c}\text { Black and } \\
\text { green Tea } \\
\text { bag }\end{array}$ & 11 & $111.2^{\mathrm{b}} \pm 253.3$ & $1.1^{\mathrm{b}} \pm 2.3$ \\
\hline
\end{tabular}

BT=Black Tea BTB= Black Tea Bag, GT= Green Tea, GTB= Green Tea Bag;

Values in the same column with different superscripts are significantly different $(\mathrm{p}<0.05)$

stimulatory effects on many enzymes and dental caries resistance. On the other hand excessive fluoride absorption from food and water as well as occupational exposure to fluoride may cause dental or skeletal fluorosis (Wong et al., 2003, Ruan \& Wang, 2001). After water, tea infusion is the most famous beverage in the world, which is an important source of fluoride intake. In Iran and middle-eastern countries, in which tea drinking is part of daily diet, tea as a beverage is an important source of fluoride intake. So, quality control of tea as a fluoride source is noticeable.

Koblar et al. (2012) assessed the human exposure to the fluoride from commercial teas. The efficacy of fluoride leaching from the green, oolong and black teas were ranged from $55-90 \%$ with continuous and $74-100 \%$ with repeated infusions, which were not affected by the type or manufacturing type. This study showed that daily consumption of five cups of tea can lead to $9-101 \%$ of adequate intake in a $70 \mathrm{~kg}$ adult. Consumption of tea with daily diet can represent $25-173 \%$ and $35-210 \%$ of fluoride adequate intake in non-fluoridated and fluoridated areas respectively. The upper limits of these intakes can be already associated with the risk of developing fluoride-related adverse effects. Further, Karak \& Bhagat (2010) reported trace amount of fluoride in tea leaves, tea and tea infusion. The amount of fluoride in 17 commercial teas (green, oolong, black and red) was reported between 170-878 $\mathrm{mg} / \mathrm{kg}$. Further, least amount was determined in oolong tea leaves $(170-224 \mathrm{mg} / \mathrm{kg})$.

In another study Mlinowska et al. (2008), determined the amount of fluoride in black, green, oolong and pu-erh tea infusions by an ion-selective electrode. Herbal infusions and instant tea were also analyzed. They concluded that brewing time (5, 10, 30 minutes) doesn't increase the fluoride amount. Fluoride content of black tea infusion (5 minutes) was more than the others. Fluoride range was reported $0.32-4.54 \mathrm{mg} / \mathrm{L}, 0.37-0.54 \mathrm{mg} / \mathrm{L}, 0.02-0.09 \mathrm{mg} / \mathrm{L}$ in black tea, white tea and herbal tea infusions, respectively. Similarly, Cao et al. (2006) assessed 37 different commercial teas 
by spectrophotometery and ion-selective electrode method to determine fluoride content and evaluate the safety of different black teas. The result showed great difference in fluoride content. The amount of fluoride was $0.95-1.41 \mathrm{mg} / \mathrm{L}$ in black tea leaves, $0.7-2.44 \mathrm{mg} / \mathrm{L}$ in granola black tea and $1.15-6.01 \mathrm{mg} / \mathrm{L}$ in black tea bags. The highest fluoride content was reported in black tea bags presumably because they are made of older and low-cost leaves. As per the WHO's recommendation 56 and $44 \%$ of the tea bags are considered unsafe for children and adults respectively. At the average rates of consumption, $24 \%$ of the black tea bags could result in the increased risk of osteofluorosis and fractures. It is concluded that $23 \%$ of the analyzed samples were unsafe for children. Regarding the results, it seems that it is necessary to do more research on the evaluation of fluoride content of beverage and food products and also run epidemiologic study on their disadvantages. Furthermore national and international organizations should evaluate developing standards about the fluoride content of tea products.

\section{Conflict of interest}

Authors would hereby like to declare that there is no conflict of interests that could possibly arise.

\section{References}

Cao J, Bai X, Zhao Y, Liu J, Zhou D, Fang S, Jia M, Wu J (1996) The relationship of fluorosis and brick tea drinking in Chinese Tibetans. Environment Health Perspective 104:1340-1343.

Cao J, Zhao Y, Li Y, Deng HJ, Yi J, Liu JW (2006) Fluoride levels in various black tea commodities: Measurement and safety evaluation. Food and Chemical Toxicology 44:1131-1137

Chung FL, Schwartz J, Herzog CR, Yang YM (2003) Tea and cancer evention: Studies in animals and humans. The Journal of Nutrition 133: 3268S-3274S.
Kakuzo O (2011) The book of tea, Benjamin Press, USA.

Karak T, Bhagat RM (2010) Trace elements in tea leaves, made tea and tea infusion: A review. Food Research International 43: 2234-2252.

Koblar A, Tavcar G, Ponikvar-Svet M (2012) Fluoride in teas of different types and forms and the exposure of humans to fluoride with tea and diet. Food Chemistry 130: 286-290.

Institute of Medicine (1997) Fluoride in "Dietary reference intakes for calcium, phosphorus, magnesium, vitamin D, and fluoride". National Academy Press. Washington, DC., USA Pp. 288-313.

Levi S, Zilberman L, Sarnat H, Amir E, Frumin A, Friedman M (1983) Fluoride: An essential or poison element. Journal of Fluorine Chemistry 23: 447.

Malinocuska E, Inkielewicz I, Caarnoucuski W, Szefer P (2008) Assessment of fluoride concentration and daily intake by human from tea an herbal infusions. Journal of Food Chemistry and Toxicology 46:1055.

Ruan JY, Wong MH (2001) Accumulation of fluoride and aluminium related to different varieties of tea plant. Environmental Geochemistry and Health 23:53-63.

Shu WS, Zhang ZQ, Lanc Y, Wong MH (2003) Fluoride and aluminum concentrations of tea plants and tea products from Sichuan province, PR china. Chemosphere $52: 1475-82$.

Webb Peploe MM, Bradley WG (1996) Endemic fluorosis with neurological complications in a Hampshire man. Journal of Neurology and Neurosurgery and Psychiatry 29 :577-583.

Wong MH, Fung KF, Carr HP (2003) Aluminium and fluoride contents of tea with emphasis on brick tea and their health implications. Toxicology Letter 137:111-120 